\title{
Obstetric History and Maternal Complications Related to Preterm Birth
}

ORIGINAL

\begin{abstract}
Gracimary Alves Teixeira', Jovanka Bittencourt Leite de Carvalho², Thais Rosental Gabriel Lopes ${ }^{3}$, Flavio César Bezerra da Silva ${ }^{4}$, Silvana Alves Pereira ${ }^{5}$, Larissa Mendonça Torres ${ }^{3}$, Juliana de Almeida Leandro Bezerra ${ }^{6}$
\end{abstract}

\section{Abstract}

Objective: To summarize knowledge produced in scientific articles about obstetric history, maternal complications and types of pregnancy as risk factors related to preterm birth.

Method: An integrative review conducted in February and March 2015, through databases: lilacs, CINAHL and Pubmed. For this it was used the Mesh descriptors: Infant, premature; Risk factors and Causality, having been found studies 50, 528. After assessment of methodological rigor and level of evidence of the studies 32 articles were selected.

Results: Among the risk factors associated to preterm birth highlighted the previous history of prematurity. Also emerged: hypertensive disease by eclampsia and eclampsia no, genitourinary infection and antiretroviral therapy in pregnancy.

Conclusion: Maternal complications are subject to screening, treatment and prevention. In addition, obstetric history of risk can be identified in a timely manner to reduce morbidity and mortality both mother and neonatal.

\section{Introduction}

Preterm birth, less than 37 weeks of pregnancy, is considered a problem of public health worldwide. That is because preterm birth is considered one of main risk factors for neonatal morbidity and mortality. [1]

1 Neonatologist nurse. Doctoral student at the Graduate of the Federal University of Rio Grande do Norte Program. CAPES scholarship holder.

2 Midwife nurse. PhD in Health Sciences, Federal University of Rio Grande do Norte. Health School professor at the Federal University of Rio Grande do Norte.

3 Nurse. Master studies at the Graduate of the Federal University of Rio Grande do Norte Program.

4 Midwife Nurse. PhD in Nursing from the Federal University of Rio Grande do Norte. Health School professor at the Federal University of Rio Grande do Norte.

5 Physiotherapist. Post PhD in Neuroscience and Behavior, University of São Paulo-USP. Specialist in Physical Therapy in Intensive Care Neonatology and Pediatrics. Adjunct Professor of Physical Therapy and Multidisciplinary Residency Program of the Federal University of Rio Grande do Norte, UFRN/FACISA/HUAB.

6 Nurse. Integrated Schools in Patos.

Contact information:

\section{Gracimary Alves Teixeira}

”gracimaryalves@yahoo.com.br

Keywords

Infant; Premature; Risk factors; Causality; Obstetric Nursing. 
Prematurity is responsible for $14 \%$ of the causes of child deaths in the world1. In addition, amount of preterm and low birth weight infants at birth has increased steadily in recent decades. Complications of preterm birth are a major cause of global neonatal deaths. In addition, number of preterm and low birth weight infants at birth has increased steadily over recent decades. Overall 11.1\% of babies are born preterm equivalent to more than 15 million children or more than 1 in 10 children. In this regard more than $60 \%$ of births occur in Africa and South Asia, however, the 10 countries with the highest rates include Brazil, the USA India and Nigeria. $[2,3,4]$

Additionally, preterm birth cause clinical consequences that require care more complex and sometimes throughout life. These types of repercussions result in a high social and economic cost to countries because preterm birth arises from a set of interrelated factors. Such factors impact upon quality of life of those who survive bearing sequels or repercussions in infant mortality [5].

This reality has aroused concern regarding the quality of prenatal and postpartum care. This concern is justified given that the fetal growth and development are important predictors of child health. Furthermore, predictors also relate to the health status in adult life [6-7]. So, it is essential the early identification of risk factors for the birth of premature baby.

Thus, following research question has emerged: What is production of scientific knowledge on obstetric history, maternal complications and types of pregnancy as risk factors related to preterm birth? Thereby, present study aims to synthesize knowledge produced in scientific articles on obstetric history, maternal complications and types of pregnancy as risk factors related to preterm birth.

\section{Method}

This study is an integrative review carried out in five steps: identification of guiding research ques- tion, search of literature in databases, evaluation of the documents concerning methodological rigor, data analysis and presentation of results. Such steps intended to develop scientific knowledge synthesis on: obstetric history, maternal complications and types of pregnancy as risk factors related to preterm birth. Allied to the synthesis also carried out there was purpose of incorporating applicability of results of significant studies in developed practice [8].

To perform integrative review, two investigators conducted searches in databases during the months of February and March 2015. Databases used were: LILACS (Literatura Latino- Americana e do Caribe em Ciências da Saúde), CINAHL (Cumulative Index to Nursing and Allied Health Literature) and Pubmed.

This quest found 50, 528 studies by using following descriptors MESH (Medical Subject Headings): Infant, premature; Risk factors and Causality. After crossing these descriptors, by Boolean operator "AND", following data resulted: Infant, premature "AND" Risk factors "AND" Causality (115 lilacs, pubmed 8534, CINAHL 01); Infant, premature "AND" Risk factors (lilacs 430, 10398 Pubmed, CINAHL 1584); Infant, premature "AND" Causality (lilacs 444, 29020 Pubmed, CINAHL 03).

Regarding the time frame it were selected studies published since 2006. It is justified this time period considering that it provides evaluation of scientific production and of current reality of the risk factors for preterm birth. Then it was proceeded by reading titles and abstracts applying the inclusion criteria: full articles electronically available and free in selected databases of capes periodic portal; published in Portuguese, English and Spanish; beyond that addressed the topic under study.

In addition, it was adopted exclusion criteria described below: letters to the editor; editorials; literature review and integrative review, cross-sectional studies, qualitative studies, which presented secondary data and/or those who did not include the theme of the present integrative review. 
The extent that these eligibility criteria were applied, repeated articles were counted only once. Full texts of these studies were transferred and stored on the computer. After these steps, complete

Table 1. Levels of evidence [9] classified in description of studies. Natal, Brazil, 2015.

\begin{tabular}{|c|c|c|}
\hline $\begin{array}{l}\text { Level } \\
\text { of } \\
\text { evidence }\end{array}$ & Methodological design & $\begin{array}{l}\text { Strength } \\
\text { of } \\
\text { evidence }\end{array}$ \\
\hline 1 & $\begin{array}{l}\text { Evidence originated by systematic } \\
\text { reviews or meta-analysis of relevant } \\
\text { clinical trials }\end{array}$ & High \\
\hline II & $\begin{array}{l}\text { Evidence derived from at least one } \\
\text { randomized controlled clinical trial } \\
\text { well outlined }\end{array}$ & High \\
\hline III & $\begin{array}{l}\text { Clinical trials well designed no } \\
\text { randomization }\end{array}$ & Moderate \\
\hline IV & $\begin{array}{l}\text { Cohort studies and case-control well } \\
\text { designed }\end{array}$ & Moderate \\
\hline V & $\begin{array}{l}\text { Systematic review of descriptive and } \\
\text { qualitative studies }\end{array}$ & Moderate \\
\hline VI & $\begin{array}{l}\text { Evidence derived from a single } \\
\text { descriptive or qualitative study }\end{array}$ & Low \\
\hline VII & $\begin{array}{l}\text { Opinion of authorities or experts } \\
\text { committees report }\end{array}$ & Low \\
\hline
\end{tabular}

Source: Research data reading of these articles was conducted by considering: methodological rigor regarding clarity of the trajectory of the method; identifying limitations and bias; evidence level for the selection and presentation of results. Whole process resulted in 32 articles (02 CINAHL, 09 LILACS, 21 of pubmed).

Thus, these articles were organized in framework containing: identification of studies, year of publication, objective, methodological design, level of evidence and place of study. Regarding level of evidence [9] studies were classified according to Table 1. Moreover, risk factors related of preterm birth; maternal reproductive history; maternal complications during pregnancy and type of pregnancy were presented descriptively and analyzed based on of the relevant literature.

\section{Results}

Table 2 shows description of the 32 studies that present risk factors related to preterm birth. It is observed predominantly in evidence IV level that is considered moderate level which corresponding to methods of Cohort and case-control. In addition, only eight of these studies were done in Brazil.

Table 2. Characterization of articles according to year of publication, study objective, method, level of evidence and place of study. Natal, Brazil, 2015.

\begin{tabular}{|c|c|c|c|c|c|}
\hline Id & $\begin{array}{c}\text { Year of } \\
\text { publication }\end{array}$ & Study objective & Method $\begin{array}{c}\text { Level of } \\
\text { evidence }\end{array}$ & $\begin{array}{c}\text { Place of } \\
\text { study }\end{array}$ \\
\hline 1A [10] & 2014 & $\begin{array}{l}\text { To determine whether there is a correlation to preterm labor and } \\
\text { vaginal microbiota during pregnancy } \\
\text { To investigate whether women who previously presented } \\
\text { abortion or termination of pregnancy have an increased risk of } \\
\text { spontaneous preterm birth }\end{array}$ & Cohort study & IV & Enited \\
States
\end{tabular}




\begin{tabular}{|c|c|c|c|c|c|}
\hline Id & $\begin{array}{c}\text { Year of } \\
\text { publication }\end{array}$ & Study objective & Method & $\begin{array}{l}\text { Level of } \\
\text { evidence }\end{array}$ & $\begin{array}{l}\text { Place of } \\
\text { study }\end{array}$ \\
\hline $1 F[15]$ & 2012 & $\begin{array}{l}\text { To identify whether the use of herbal products during pregnancy is very common and whether everyday use of } \\
\text { almond oil spread in the skin is associated with premature birth }\end{array}$ & Cohort study & IV & Italy \\
\hline $1 G[16]$ & 2012 & $\begin{array}{l}\text { To investigate the association between sociodemographic data and obstetrical risk factor in preterm birth in five } \\
\text { hospitals of Maternal and Child Health in Beijing, China }\end{array}$ & Case-control study & IV & China \\
\hline $1 \mathrm{H}[17]$ & 2012 & $\begin{array}{l}\text { To investigate whether there is an association between use of antiretroviral combination therapy during pregnancy } \\
\text { by women infected with HIV and risk of prematurity }\end{array}$ & Cohort study & IV & France \\
\hline 11 [18] & 2012 & To analyze determinants of low birth weight, small for pregnancy and premature births in Lombok, Indonesia & $\begin{array}{l}\text { Randomized clinical } \\
\text { trial }\end{array}$ & II & Indonesia \\
\hline 1J [19] & 2012 & To determine the genitourinary infections as risk factors for preterm birth in teenagers & Case-control study & IV & Mexico \\
\hline $1 \mathrm{~K}[20]$ & 2012 & To analyze the risk factors for preterm birth in the city of Campina Grande, State of Paraiba, Brazil & Case-control study & IV & Brazil \\
\hline $1 \mathrm{~L}[21]$ & 2011 & $\begin{array}{l}\text { To determine the bio-psycho-social risk factors for preterm birth in a sample of Turkish women without chronic } \\
\text { diseases and evaluate their anxiety and depression in early postpartum period }\end{array}$ & Case-control study & IV & Europe \\
\hline $1^{\circ}[23]$ & 2011 & $\begin{array}{l}\text { To examine the associations between systolic and diastolic blood pressure in different trimesters of pregnancy and } \\
\text { both fetal growth characteristics measured repeatedly and risks of adverse birth }\end{array}$ & Cohort study & IV & Holand \\
\hline $1 \mathrm{P}[24]$ & 2011 & $\begin{array}{l}\text { To investigate whether the use of highly active antiretroviral therapy (HAART) during pregnancy has been linked to } \\
\text { premature births }\end{array}$ & $\begin{array}{l}\text { Randomized clinical } \\
\text { trial }\end{array}$ & ॥ & $\begin{array}{l}\text { United } \\
\text { States }\end{array}$ \\
\hline $1 R[25]$ & 2011 & $\begin{array}{l}\text { To analyze the relationship of gestational Malaria and its effects in newborns in a region endemic for malaria in } \\
\text { Colombia between } 1993 \text { and } 2007\end{array}$ & Cohort study & IV & Colombia \\
\hline 15 [26] & 2011 & $\begin{array}{l}\text { To evaluate the relationship between presence of Chlamydia trachomatis and placenta signs of inflammation in } \\
\text { women who gave birth at } 32 \text { weeks gestation or less }\end{array}$ & Cohort study & IV & Holand \\
\hline 1T [27] & 2011 & $\begin{array}{l}\text { To evaluate the risks of preterm delivery and hypertensive disease specific to pregnancy among pregnant women } \\
\text { with mood disorders and migraine }\end{array}$ & Cohort study & IV & $\begin{array}{l}\text { United } \\
\text { States }\end{array}$ \\
\hline
\end{tabular}




\begin{tabular}{|c|c|c|c|c|c|}
\hline Id & $\begin{array}{c}\text { Year of } \\
\text { publication }\end{array}$ & Study objective & Method & $\begin{array}{l}\text { Level of } \\
\text { evidence }\end{array}$ & $\begin{array}{l}\text { Place of } \\
\text { study }\end{array}$ \\
\hline $1 \cup[28]$ & 2010 & $\begin{array}{l}\text { To evaluate effects of non-surgical treatment of periodontal disease during second trimester of pregnancy on } \\
\text { adverse pregnancy }\end{array}$ & Clinical trial & III & Brazil \\
\hline $1 \mathrm{~V}[29]$ & 2010 & To determine whether there are differences in risk factors for preterm birth in different income levels & Cohort study & IV & Brazil \\
\hline $1 \times[30]$ & 2010 & $\begin{array}{l}\text { To evaluate periodontitis of moderate to severe in pregnant as risk factors for prematurity, premature rupture of } \\
\text { membranes and low birth weight }\end{array}$ & Cohort study & IV & Argentina \\
\hline $1 Y[31]$ & 2010 & $\begin{array}{l}\text { To evaluate relationship among housing conditions and low birth weight and prematurity associated to low birth } \\
\text { weight in children of low-income women }\end{array}$ & Case-control study & IV & Brazil \\
\hline $1 Z[32]$ & 2009 & $\begin{array}{l}\text { To relate maternal exposure to risk factors for preterm births at the Hospital Nossa Senhora da Conceição, in } \\
\text { Tubarão (SC), from June to November } 2008\end{array}$ & Case-control study & IV & Brazil \\
\hline $1 \mathrm{~W}[33]$ & 2009 & To point out factors associated with preterm birth in a hospital in the city of Londrina, Parana State, & Case-control study & IV & Brazil \\
\hline $2 \mathrm{~A}[34]$ & 2008 & $\begin{array}{l}\text { To evaluate whether domestic violence during pregnancy is related to unfavorable infant health, measured by low } \\
\text { birth weight or prematurity }\end{array}$ & Cohort study & IV & Brazil \\
\hline $2 C[35]$ & 2008 & To evaluate periodontal disease as a risk factor for low birth weight premature & Case-control study & IV & Turkey \\
\hline 2D [36] & 2008 & $\begin{array}{l}\text { To investigate whether endothelial dysfunction as assessed by high cell fibronectin (CFn), in women with pre- } \\
\text { eclampsia is associated with an increased risk of preterm }\end{array}$ & Case-control study & IV & $\begin{array}{l}\text { United } \\
\text { States }\end{array}$ \\
\hline $2 \mathrm{E}[37]$ & 2007 & $\begin{array}{l}\text { To identify risk factors associated to birth of newborns very low birth weight in the Hospital Geral de Caxias do Sul, } \\
\text { Rio Grande do Sul, Brazil }\end{array}$ & Case-control study & IV & Brazil \\
\hline $2 F[38]$ & 2007 & To determine association between maternal body mass index and risk of preterm delivery & Case-control study & IV & Scotland \\
\hline 2G [39] & 2007 & $\begin{array}{l}\text { To investigate the role of genetic variation of progesterone receptor gene (PGR) in modulating risk for preterm labor, } \\
\text { examining maternal and fetal effects }\end{array}$ & Case-control study & IV & $\begin{array}{l}\text { United } \\
\text { States }\end{array}$ \\
\hline $2 \mathrm{H}[40]$ & 2007 & $\begin{array}{l}\text { Measure the risk of premature labor, premature rupture of membranes, low birth weight and infant mortality } \\
\text { associated to Chlamydia }\end{array}$ & Cohort study & IV & $\begin{array}{l}\text { United } \\
\text { States }\end{array}$ \\
\hline 2I [41] & 2006 & To identify factors associated to pregnant women with diagnoses of preterm & Case-control study & IV & Spain \\
\hline
\end{tabular}


Table 3. Risk factors of preterm birth according to categories. Natal, Brazil, 2015.

\begin{tabular}{|c|c|}
\hline Categories & Risks Factors Related To Preterm Birth \\
\hline \multirow{8}{*}{$\begin{array}{l}\text { Obstetric } \\
\text { history }\end{array}$} & $\begin{array}{l}\text { Previous history of prematurity }[16,20-21, \\
29,31-34,42]\end{array}$ \\
\hline & High blood pressure $[29,37]$ \\
\hline & Reproductive abnormalities [16] \\
\hline & Primiparity [29] \\
\hline & Two to four previous miscarriages [11] \\
\hline & Reproductive history assisted [33] \\
\hline & Previous chid of low birth weight [37] \\
\hline & Nulliparous with morbidly obese [38] \\
\hline \multirow{22}{*}{$\begin{array}{l}\text { Maternal } \\
\text { complications }\end{array}$} & $\begin{array}{l}\text { Hypertensive disease with eclampsia and no } \\
\text { eclampsia }[16,20,27,33]\end{array}$ \\
\hline & Preeclampsia $[23,36,41]$ \\
\hline & Genitourinary infection [19, 21, 32-33] \\
\hline & Vaginal bleeding $[20,32-33]$ \\
\hline & Bacterial vaginosis $[10,32,35]$ \\
\hline & $\begin{array}{l}\text { Antiretroviral therapy in pregnancy }[13,17 \text {, } \\
22,24]\end{array}$ \\
\hline & Periodontal disease $[28,30,35]$ \\
\hline & Altered amniotic fluid volume $[20,33]$ \\
\hline & Premature rupture of membranes [41] \\
\hline & Placenta previa [16] \\
\hline & Chlamydia $[26,41]$ \\
\hline & Maternal syphilis [12] \\
\hline & Malaria [25] \\
\hline & Pyelonephritis [32] \\
\hline & Gestational diabetes mellitus [16] \\
\hline & Pregnant women infected by HIV [17] \\
\hline & Diarrhea [18] \\
\hline & Edema $[18]$ \\
\hline & Maternal physical injury [20] \\
\hline & $\begin{array}{l}\text { Antepartum haemorrhage associated to } \\
\text { intimate partner violence [14] }\end{array}$ \\
\hline & $\begin{array}{l}\text { Herbal consumption (Almond oil, } \\
\text { chamomile and fennel) during pregnancy } \\
\text { [15] }\end{array}$ \\
\hline & Genetic variation in progesterone gene [39] \\
\hline $\begin{array}{l}\text { Type of } \\
\text { pregnancy }\end{array}$ & Twin pregnancy $[32-33,41]$ \\
\hline
\end{tabular}

Source: Research data
Table 3 shows risks factors related to preterm birth according to categories: obstetric history, maternal complications and type of pregnancy. Among factors stood out prior history of preterm birth, hypertensive disease with eclampsia and no eclampsia, genitourinary infection and antiretroviral therapy in pregnancy.

\section{Discussion}

Results presented that only 8 of the 32 studies were carried out in Brazil. methodological design of Cohort study and case-control was the best and both present moderate level of evidence. However, the case-control method aims to identify risk factors which this study proposes.

In this search, risk factors related to preterm birth that were identified are the following: a history of preterm birth, hypertensive disease with eclampsia and no eclampsia, genitourinary infection and antiretroviral therapy in pregnancy. In addition to this are twin pregnancy, vaginal bleeding and bacterial vaginosis.

The previous history of prematurity was one risk factor associated with prematurity which appeared more repeatedly in studies under review. In the articles consulted previous prematurity was described as jointly responsible for influencing by up to 2.37 times episodes of preterm birth in subsequent pregnancies [20].

Given the risks of chronic hypertension and / or gestational for mother and baby dyad, World Health Organization (WHO) recommends a minimum of 6 prenatal consultations. Blood pressure and weight should be checked in all consultations to identify possible complications in a timely manner. [4] That is because overweight and obesity increases the risk of preeclampsia and women should preferentially point normal weight before pregnancy. [42]

Following these guidelines of $\mathrm{WHO}$, the Ministry of Health $(\mathrm{MH})$ of Brazil establishes the procedure for hypertensive sídromes of pregnancy according 
to the classification: mild pre-eclampsia, severe pre-eclampsia, eclampsia, acute hypertension and HELLP syndrome. This classification is designed to minimize damage to maternal and child health. Specifically for eclampsia, $\mathrm{MH}$ recommends that in case the pregnant woman is with gestational age greater than or equal to 34 weeks she should be prepared for pregnancy termination or delivery [43].

Additionally, preterm birth can be caused by interrelated factors, such as: genitourinary infection, factors associated with premature rupture of membranes, premature labor and chorioamnionitis. Through the release of endotoxins and exotoxins arising from the urinary tract infection, it begins the process of parturition because the infection exacerbates uterine contractility and maturation of the cervix. This leads to premature birth occurs [44].

Thus, about $17 \%$ to $20 \%$ of pregnant women have clinical condition symptomatic of Urinary Tract Infection (UTI) mediated by hormones that cause glycosuria and aminoaciduria favorable to microbial growth and infections. The UTI ranges from asymptomatic bacteriuria which can progress to acute pyelonephritis, but also may develop inro cystitis. Thus, the $\mathrm{MH}$ recommends performing urinalysis during prenatal low risk periods in the first and third trimester of pregnancy. In addition, all pregnant women with evidence of bacteriuria should be treated. This is intended to serve as a preventive measure of progression to cystitis or pyelonephritis which cause complications to the health of the mother-infant dyad $[45,46]$.

Even though studies suggest the Antiretroviral Therapy (ART) as a risk factor for preterm birth, $\mathrm{MH}$ of Brazil recommends its prescription in pregnancy as prophylaxis of vertical transmission or treatment of infection to Human Immunodeficiency Virus (HIV). This ART should be initiated after first trimester of pregnancy. That is because rate of vertical transmission of HIV without intervention stands at approximately $25.5 \%$. Thus, it is possible to re- duce vertical transimssão through ART combined with: elective cesarean delivery; chemoprophylaxis of azidothymidine (AZT) in laboring women and newborn; besides not breastfeeding [43]. However, despite the benefit of reducing vertical transmission study indicates that antiretroviral therapy can increase the risk of pulmonary arterial hypertension in pregnant women [47].

Corroborating with other risk factors, twin pregnancy is presented as predisposition to complications such as: vaginal bleeding, congenital anomalies and preeclampsia which culminate in preterm birth and low birth weight. Thus, it is necessary to detect pathological changes of women in multiple pregnancy and to intervene in prevention of greater damages to mothers and children [48].

Therefore, early identification of women at risk of preterm delivery allows the use of strategies that may postpone occurrence of delivery till conditions are viable for the mother-infant pair. Thus, it is possible to reduce maternal and neonatal morbidity and mortality. In this sense, the Family Health Strategy (FHS) is a technological innovation not material in area of Brazilian health policy. This strategy adopts a broader concept of the health-disease through promotion, prevention, cure and rehabilitation. Therefore it can be expanded to offer assistance to people and community in an area linked to the services provided [49].

\section{Conclusion}

The study found several risk factors related to preterm birth among which are obstetric history and maternal complications. There was emphasis in the quantitative of research on the previous history of prematurity. In addition, these articles also revealed other risk factors such as maternal complications amenable to screening, treatment and prevention.

Among complications cited are hypertensive disease with eclampsia and no eclampsia and genitourinary infections associated with premature bir- 
th. Furthermore, antiretroviral therapy has also been found as a risk factor for preterm birth.

Therefore, through the synthesis of scientific knowledge produced in this study, it is expected to contribute to the knowledge of physicians and midwives of the Family Health Strategy which provide maternal and infant care. From this, there is the intention to create opportunities expanded vision to professionals so that they can identify in a timely manner women with risk factors associated to preterm birth. These professionals can then minimize complications and reduce maternal and neonatal morbidity and mortality based on scientifically supported results.

\section{References}

1. World Health Organization (WHO). Levels and trendes in child mortality 2012. [Internet]. 2012 [cited 2015 Feb 15]; [about. 7 p]. Available from: http://www.idf.org/webdata/docs/Metac syndrome def.pdf.

2. Kenner C, Boykova M. Enfermagem neonatal em um contexto global: principais realizações e progressos. Programa de Atualiação em Enfermagem (PROENF)-Saúde Materna e Neonal. 2014;5(2):9-46.

3. Black RE, et al. Global, regional, and national cuases os child mortality in 2008: a systematic analysis. Lancet. 2010 [cited 2016 Jul 04]; 375(9730):1969-87. Available from: http://www. ncbi.nlm.nih.gov/pubmed/20466419

4. Partnership for Maternal Newborn and Child Health. Born too soon: the global action report on preterm birth [internet] 2012 [cited 2015 Jan 25]. Available from: http://www.who.int/pmnch/ media/news/2012/preterm birth report/en/. Internet] 2010 [cited 2015 Mar 26]; [8(1 Pt 1):102-6]. Available from: http:// www.astresmetodologias. com/material/O que e RIL.pdf.

5. Assunção PL, Novaes HMD, Alencar GP, Melo ASO, Almeida MF. Fatores associados ao nascimento pré-termo em Campina Grande, Paraíba, Brasil: um estudo caso-controle. Cad. Saúde Pública, 2012;28(6):1078-90.

6. Goldenberg RL, Culhane JF, lams JD, Romero R. Epidemiology and causes of preterm birth. Lancet. 2008; 371:75-84.

7. Lawn JE, Gravett MG, Nunes TM, Rubens CE, Stanton C; GAPPS Review Group. Global report on preterm birth and stillbirth (1 of 7): definitions, description of the burden and opportunities to improve data. BMC Pregnancy Childbirth 2010; 10 Suppl 1:S1.
8. Souza MT, Silva MD, Carvalho R. Revisão integrativa: o que é e como fazer. Einstein. [Internet] 2010 [cited 2015 Mar 26]; [8(1 Pt 1):102-6]. Available from: http://www.astresmetodologias. com/material/O que e RIL.pdf.

9. Melnyk BM, Fineout-Overholt E. Making case for evidence based practice. In: Melnyk BM, Fineou-Overholt E. Evidence based practice in nursing \& healthcare. A guide to practice. Philadelphia: Lippincot Williams \& Wilkins; 2005.

10. Hyman RW, Fukushima M, Jiang H,Fung E, Rand L, Johnson B,et al. Diversity of the Vaginal Microbiome Correlates With Preterm Birth. Reproductive Sciences. [Internet] 2014 [cited 2010 Feb 26]; [21(1): 32-40]. Available from: http://rsx.sagepub.com/ content/early/2013/05/27/1933719113488838.

11. McCarthy FP, Khashan AS, North RA, Rahma MB, Walker J, Baker PN, et al. On behalf of the SCOPE Consortium. Pregnancy loss managed by cervical dilatation and curettage increases the risk of spontaneous preterm birth. Human Reproduction. [Internet] 2013 [cited 2015 Feb 10]; [28(12):3197-206]. Available from: $\quad$ http://humrep.oxfordjournals.org/content/28/12/3197. short.

12. Gomez GB, Kamb ML, Newman LM, Mark J, BroutetcN, Hawkesd SJ. Untreated maternal syphilis and adverse outcomes of pregnancy: a systematic review and meta-analysis. Bull World Health Organ 2013; [cited 2015 Fev 10]; [91:217-26]. Available from: http://www.scielosp.org/scielo.php?pid=S004296862013000300013\&script=sci arttext

13. Watts DH, Williams PL, Kacanek D, Griner R, Rich K, Hazra R, et al. Combination Antiretroviral Use and Preterm Birth. The Journal of Infectious Diseases. [Internet] 2013 [cited 2015 Feb 12]; [207:612-21]. Available from: http://jid.oxfordjournals.org/ content/207/4/612.full.

14. Watson LF, Taft AJ. Intimate Partner Violence and the Association with Very Preterm Birth. . [Internet] 2013 [cited 2015 Feb 12]; [40(1):17-23]. Available from: http://onlinelibrary.wiley.com/ doi/10.1111/birt.12024/abstract.

15. Facchinetti F, Pedrielli G, Benoni G, Joppi M, Verlato G, Dante $G$, et al. Herbal supplements in pregnancy: unexpected results from a multicentre study. Human Reproduction. [Internet] 2012 [cited 2015 Feb 12]; [27(11): 3161-67]. Available from: http://humrep.oxfordjournals.org/ content/27/11/3161.short.

16. Zhang YP, Liu XH, Gao SH, Wang JM, Gu YS, Zhang JY, et al. Risk Factors for Preterm Birth in Five Maternal and Child Health Hospitals in Beijing. Plos one. [Internet] 2012 [cited 2015 Feb 12]; [7: 12]. Available from: http://journals.plos.org/plosone/ article?id=10.1371/journal.pone.0052780.

17. Sibiude J, Warszawski J, Tubiana R, Dollfus C, Faye A, Rouzioux $C$, et al. Premature Delivery in HIV-Infected Women Starting Protease Inhibitor Therapy During Pregnancy: Role of the Ritonavir Boost? Clinical Infectious Diseases. [Internet] 2012 [cited 2015 Feb 6]; [54(9):1348-60]. Available from: http://cid. oxfordjournals.org/content/54/9/1348. short. 
18. SebayangSK, Dibley MJ, Kelly PJ, Shankar AV,Shankar AH. Determinants of low birthweight, small-for-gestational-age and preterm birth in Lombok, Indonesia: analyses of the birthweight cohort of the SUMMIT Trial. Trop Med Int Health. 2012aug; 17(8):938-50. Disponível em: http://onlinelibrary.wiley.com/ doi/10.1111/j.1365-3156.2012.03039.x/full [acesso: 2015 Fev 16]

19. Ugalde-Valencia D, Hernández-Juárez MG, Ruiz-Rodríguez MA, Villarreal-Ríos E. Infecciones del tracto genital y urinario como factores deriesgo para parto pretérmino en adolescentes. Rev chil obstet ginecol. [Internet] 2012 [cited 2015 Feb 16]; [77(5):338-41]. Available from: http://www.scielo.cl/scielo. php?script=sci arttext\&pid=S0717-75262012000500003.

20. Assunção PL, Novaes HMD, Alencar GP, Melo ASO, Almeida MF. Fatores associados ao nascimento pré-termo em Campina Grande, Paraíba, Brasil: um estudo caso-controle Cad. Saúde Pública. 2012;28(6):1078-90.

21. Ilkay G, Umran O, Kizilkaya BN. Biopsychosocial risk factors for preterm birth and postpartum emotional well-being: a case-control study on turkish women without chronic illnesses. J clin nurs. [Internet] 2011 [cited 2015 Feb 18]; [20(5/6):653-65]. Available from: http://www.ncbi.nlm.nih.gov/ pubmed/21320194.

22. Van der Merwe $K$, Hoffman $R$, Black V, Chersich $M$, Coovadia A, Rees H. Birth outcomes in South African women receiving highly active antiretroviral therapy: a retrospective observational study. J Int AIDS Soc. [Internet] 2011 [cited 2015 Feb 18]; [14:42]. Available from: http://www.ncbi.nlm.nih.gov/ pubmed/21843356.

23. Bakker R, Steegers EAP, Hofman A, Jaddoe VWV. Blood Pressure in Different Gestational Trimesters, Fetal Growth, and the Risk of Adverse Birth Outcomes. Am J Epidemiol. 2011; 174(7):797-806.

24. Powis KM, Kitch D, Ogwu A, Hughes MD, Lockman S, Leidner J,et al. Increased Risk of Preterm Delivery Among HIVInfected Women Randomized to Protease Versus Nucleoside Reverse Transcriptase Inhibitor-Based HAART During Pregnancy. J Infect. Dis. [Internet] 2011 [cited 2015 Feb 18]; [204(4):506-14]. Available from: http://www.ncbi.nlm.nih.gov/pubmed/21791651.

25. Tobón-Castaño A, Solano MA, Sánchez LGA, Trujillo SB. Retardo no crescimento intrauterino, baixo peso ao nascer e prematuridade em recém-nascidos de grávidas com malária, na Colômbia. Rev. Soc Bras Med Tropical. 2011; 44(3):364-70.

26. Rours GIJG, Krijger RR, Ott A, Willemse HFM, Groot $R$, Zimmermann LJI, et al. Chlamydia trachomatis and placental inflammation in early preterm delivery Eur. J Epidemiol. [Internet] 2011 [cited 2015 Feb 18]; [26:421-28]. Available from: 2011;. Disponível em: http://link.springer.com/article/10.1007/s10654011-9569-2\#page-1.
27. Cripe SM, Frederick IO, Qiu C, Williams MA. Risk of Preterm Delivery and Hypertensive Disorders of Pregnancy in Relation to Maternal Comorbid Mood and Migraine Disorders during Pregnancy. Paediatr Perinat Epidemiol. [Internet] 2011 [cited 2015 Feb 20]; [116-23]. Available from: http://onlinelibrary. wiley.com/doi/10.1111/j.13653016.2010.01182.x/bstract?userls Authenticated $=$ false $\&$ deniedAccessCustomisedMessage $=$

28. Sant'ana ACP, Campos MR, Passanezi SC, Rezende MLR, Greghi SLA, Passanezi E. Periodontal treatment during pregnancy decreasesthe rate of adverse pregnancy outcome:a controlled clinical Trial.J Appl Oral Sci. [Internet] 2011 [cited 2015 Feb 20]; [19(2):130-6]. Available from: http://www.scielo.br/scielo. php?pid=S1678-77572011000200009\&script=sci arttext.

29. Silveira MF, Victora CG, Barros AJD, Santos IS, Matijasevich A, Barros FC. Determinants of preterm birth: Pelotas, Rio Grande do Sul, Brazil,2004 birth cohort. Cad. Saúde Pública. [Internet] 2010 [cited 2015 Feb 23]; [185-94]. Available from: http://www. scielosp.org/scielo.php?pid=S0102311X2010000100019\&script

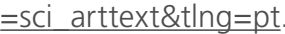

30. Wolff FC, Ribotta AEM, Jofré ME. Riesgo de Complicaciones Perinatales en Embarazadas com Periodontitis Moderada y Severa, en La Ciudad de Córdoba. Rev. Clin. Periodoncia Implantol. Rehabil. Oral. [Internet] 2010 [cited 2015 Feb 24]; [3(2):73-8]. Available from: http://www.scielo.cl/scielo. php?pid=S0719-01072010000200003\&script=sci arttext.

31. Vettore MV, Gama SGN, Lamarca GA, Schilithz AOC, Leal MC. Housing conditions as a social determinant of low birthweight and preterm low birthweight. Rev Saúde Pública. 2010Dez; 44(6):1021-31.

32. Silva LA, Silva RGA, Rojas PFB, Laus FF, Sakae TM. Fatores de risco associados ao parto pré-termo em hospital de referência de Santa Catarina. Revista da AMRIGS. [Internet] 2009 [cited 2015 Feb 27]; [53(4): 354-60]. Available from: http://www.researchgate. net/profile/Thiago Sakae/publication/237585301 Fatores de risco associados ao parto prtermo em hospital de referncia de Santa Catarina Risk factors associated with preterm_labors_in_a_reference_hospital_in_Santa_Catarina/ links/54c17b470cf2d03405c593f0.pdf.

33. Silva AMR, Almeida MF, Matsuo T, Soares DA. Fatores de risco para nascimentos pré-termo em Londrina, Paraná, Brasil. Cad. Saúde Pública. 2009 out; 25(10):2125-38.

34. Audi CAF, Corrêa AMS, Latorre MRDO, Santiago SM. The association between domestic violence during pregnancy and low birth weight or prematurity. J Pediatr. [Internet] 2008 [cited 2015 Mar 10]; [84(1): 60-7]. Available from: http://www.scielo. br/scielo.php?pid=S0021-75572008000100011\&script=sci_ arttext. 
35. Marakoglu I, Gursoy UK, Marakoglu K, Cakmak H, Ataoglu T. Periodontitis as a Risk Factor for Preterm Low Birth Weight. J Yonsei Med. [Internet] 2008 [cited 2015 Mar 12]; [49(2):2003]. Available from: http://synapse.koreamed.org/search. php? where $=$ aview\&id=10.3349/ymj. 2008.49.2.200\&cod $=$ 0069YMJ\&vmode=FULL.

36. Powers RW, Catov JM,Bodnar LM, Gallaher MJ, Lain KY, Roberts JM. Evidence of Endothelial Dysfunction in Preeclampsia and Risk of Adverse Pregnancy Outcome. Reprod Sci. [Internet] 2008 [cited 2015 Mar 13]; [15(4):374-81]. Available from: http://rsx. sagepub.com/content/early/2008/01/09/1933719107311780. short.

37. Araújo BF, Tanaka ACA. Fatores de risco associados ao nascimento derecém-nascidos de muito baixo peso em umapopulação de baixa renda Cad. Saúde Pública. 2007; 23(12):2869-77.

38. Smith GCS, Shah I, Pell JP, Crossley JA, Dobbie R. Maternal Obesity in Early Pregnancy and Risk of Spontaneous and Elective Preterm Deliveries: A Retrospective Cohort Study American. J Public Health. [Internet] 2007 [cited 2015 Mar 13]; [97(1):15762]. Available from: http://journals.lww.com/obgynsurvey/ Abstract/2007/05000/Maternal Obesity in Early Pregnancy and Risk of.10.aspx.

39. Ehn NL, Cooper ME, Orr K, Shi M,Johnson MK,Caprau D, et al. Evaluation of Fetal and Maternal Genetic Variation in theProgesterone Receptor Gene for Contributions to Preterm Birth. Pediatr Res. [Internet] 2007 [cited 2015 Mar 17]; [62(5):630-35]. Available from: http://www.nature.com/pr/ journal/v62/n5/abs/pr2007291a.html.

40. Blas MM, Canchihuaman FA, Alva IE, Hawes SE. Pregnancy outcomes in women infected with Chlamydia trachomatis: a population-based cohort study in Washington State. Sex Transm Infect. [Internet] 2007 [cited 2015 Mar 19]; [83: 314-18. Available from: http://sti.bmj.com/content/83/4/314.short.

41. Jaramillo-Prado JJ, López-Giraldo IR, Arango-Gómez F. Factores asociados con partopretérmino en el tercer nivel de atención en salud en manizales. Rev Colombiana de Obstetricia y Ginecología. [Internet] 2006 [cited 2015 Mar 27]; [57(2): 74-81]. Available from: http://www.scielo.org.co/scielo.php?pid=\$0034$74342006000200002 \&$ script=sci_abstract.

42. Persson $M$, Cnattingius $S$, Wikström AK, Johansson S. Maternal overweight and obesity and risk of pre-eclampsia in women with type 1 diabetes or type 2 diabetes. Diabetologia. [Internet] 2016 Jul [cited 2016 Jul 05]. [Epub ahead of print]. Available from: http://www.ncbi.n/m.nih.gov/pubmed/27369871

43. Brasil. Gestação de alto risco: manual técnico. Brasília (DF): Ministério da Saúde,2010.

44. Montenegro CAB, Rezende Filho J. Rezende Obstetrícia Fundamental. 13a edição. Rio de Janeiro: Guanabara Koogan, 2014.

45. Brasil. Atenção ao pré-natal de baixo risco. Brasília (DF): Ministério da Saúde, 2012.
46. Ashorn $P$, Vanhala $H$, Pakarinen $O$, Ashorn U, De Costa A. Prevention of Intrauterine Growth Restriction and Preterm Birth with Presumptive Antibiotic Treatment of Pregnant Women: A Literature Review. Nestle Nutr Inst Workshop Ser. 2015;81:37-50. Available from: http://www.ncbi.nlm.nih.gov/ pubmed/26111562 [cited $2016 \mathrm{Jul} 05$ ]

47. Madi JM, Araújo BF, Zatti $H$, Rombaldi RL, Lorencetti J, Pinson $G$, et al. Avaliação dos fatores associados à ocorrência de prematuridade em um hospital terciário de ensino. Revista da AMRIGS. [Internet] 2012 [cited 2015 Jun 27]; [56(2):1118]. Available from: http://www.amrigs.com.br/ revista/56-02/ original2.pdf

48. Stoner MC 1, Vwalika B 2, Smid MC 3 , George S 2 , Chi BH 3 , Stringer EM 3, Stringer JS 4 . A retrospective study of HIV, antiretroviral therapy, and pregnancy-associated hypertension among women in Lusaka, Zambia. Int J Gynaecol Obstet. 2016 [cited 2016 Jul 05]; [Epub ahead of print]. Available from: http://www.ncbi.nlm.nih.gov/pubmed/27365290

49. Soratto J, Pires DEP, Dornelles S, Lorenzetti J. Estratégia saúde da família: uma inovação tecnológica em saúde. Texto Contexto Enferm. 2015; 24(2): 584-92.

\section{Publish in International Archives of Medicine}

International Archives of Medicine is an open access journal publishing articles encompassing all aspects of medical science and clinical practice. IAM is considered a megajournal with independent sections on all areas of medicine. IAM is a really international journal with authors and board members from all around the world. The journal is widely indexed and classified Q1 in category Medicine. 